\title{
Peripheral Benzodiazepine Binding Sites in Platelets of Patients Affected by Mitochondrial Diseases and Large Scale Mitochondrial DNA Rearrangements
}

\author{
Claudia Martini, ${ }^{1}$ Beatrice Chelli, ${ }^{1}$ Laura Betti, ${ }^{1}$ Marina Montali, ${ }^{1}$ Michelangelo Mancuso, ${ }^{2}$ \\ Gino Giannaccini, ${ }^{1}$ Anna Rocchi, ${ }^{2}$ Luigi Murri, ${ }^{2}$ and Gabriele Siciliano ${ }^{2}$ \\ ${ }^{\mathrm{l}}$ Department of Psychiatry, Neurobiology, Pharmacology and Biotechnology \\ ${ }^{2}$ Department of Neurosciences, Neurological Clinics, University of Pisa, Pisa, Italy \\ Accepted October 23, 2002
}

\begin{abstract}
Background: The peripheral-type benzodiazepine receptors (PBR) are localized on the outer mitochondrial membrane, as a constituent of mitochondrial permeability transition (MPT)-pore. Among its hypothesized functions, the regulation of the mitochondrial respiratory chain and apoptosis have been suggested; in addition alterations of PBR site density have been shown in some neuropathologic conditions with putative mitochondrial involvement. The aim of this work has been to evaluate PBR kinetic binding parameters in platelets from patients affected by mitochondrial disorders (MD) with large-scale mitochondrial DNA deletions and reduced cytochrome c oxidase activity.

Materials and Methods: Using the specific PBR radioligand $\left[{ }^{3} \mathrm{H}\right]$ PK 11195, the kinetic binding parameters of
\end{abstract}

PBR sites were determined in platelet membrane of 15 healthy subjects and 11 patients affected by different form of MD.

Results: Significant changes of dissociation constant $\left(K_{\mathrm{d}}\right)$ and maximal number of binding sites $\left(B_{\max }\right)$ values were evidenced in platelets of patients versus controls. In all patients the $B_{\max }$ values were decreased $(2387.0 \pm 305.6 \mathrm{fmol} /$ $\mathrm{mg}$ proteins versus $4889.0 \pm 357.8 \mathrm{fmol} / \mathrm{mg}$ proteins, $p<$ $0.05)$, whereas the $K_{\mathrm{d}}$ values were higher in patients than controls (13.18 $\pm 2.06 \mathrm{nM}$ versus $5.63 \pm 0.46 \mathrm{nM}, p<0.05)$. Conclusions: These data suggest that the kinetic binding parameters of PBR are altered in MD and that the observed changes might be related to the mitochondrial dysfunction associated with MD.

\section{Introduction}

The mitochondrial disorders (MD) are genetically and phenotypically heterogeneous groups of disorders caused by structural and functional abnormalities in mitochondria. More conventionally, the term $M D$ is used to indicate diseases caused by defects of the mitochondrial respiratory chain (electron transport chain [ETC]), mostly due to mutations in oxidative phosphorylation (Oxphos) genes (1).

Impaired ETC functioning leads to a number of deleterious consequences including decreased ATP production, impaired calcium buffering, and generation of free radicals. These changes lead to further mitochondrial damage such as oxidation of mitochondrial DNA (mtDNA), proteins, and lipids. The decline in mitochondrial energy production and the increase in oxidative stress can also impinge on the opening of the mitochondrial permeability transition (MPT)-pore (2), responsible for the mitochondrial membrane permeabilization, an early step of both apoptotic and necrotic cell death (3-5). Recently,

Address correspondence and reprint requests to: Gabriele Siciliano, Department of Neurosciences, Neurological Clinics, University of Pisa, Via Roma 67 -56126, Pisa, Italy. Phone: +39-050-993046/2905; fax: +39-050-554-808; e-mail: gsicilia@med.unipi.it apoptotic cell death has also been observed in skeletal muscle of patients with ETC defects and other metabolic myopathies, including MD (6), and in cybrids model carrying a point mutation, which is located in the tRNALeu (UUR) gene of mtDNA, responsible for mitochondrial encephalomyopathy (MELAS syndrome) (7).

Although the exact protein composition of the MPT pore is poorly understood, it is known that several proteins such as the voltage-dependent anion channel or porin, the adenine nucleotide translocator, the peripheral benzodiazepine receptor (PBR), and apoptosis-regulatory proteins from the Bax/Bcl-2 family are its important constituents $(4,8)$.

PBR is a 18,000 -dalton transmembrane spanning protein, distinct from the central-type benzodiazepine receptor (CBR), expressed in almost all the peripheral mammalian tissues, including blood cells, and also in glial cells in the brain (9-11). Although the precise function of the PBR remains an enigma, recent studies suggest that the PBR takes part in the regulation of the mitochondrial permeability and induction of apoptosis $(12,13)$.

Interestingly, PBR density is modulated under a variety of physiologic or pathologic conditions. Several pathologic states including stress $(14,15)$, 
seizures (16), Wernicke's encephalopathy (17), Alzheimer's disease (18), Huntington's disease (19), and trauma (20) are also associated with changes in PBR expression.

Based on these considerations and to evaluate whether PBR involvement occurs in MD, the aim of the present study has been to assess, compared to controls, the kinetic binding parameters of the specific PBR ligand, PK 11195, in platelets from 11 patients affected by MD with large scale mtDNA rearrangements.

\section{Materials and Methods}

\section{Selection of Patients}

Eleven patients with a clinical-molecular diagnosis of MD ( 3 men and 8 women, mean age $55.1 \pm 15.7$ years, range 27-74) entered the study (Table 1). Fifteen age- and sex-matched volunteers $(5$ men and 10 women, aged $42.3 \pm 8.6$ years, range $30-81$ ) were recruited as controls. Our institution's Committee on Human Experimentation approved the investigation protocol. The purpose and procedure of the study was explained to each subject who gave his/her informed consent. No patient was taking medications for at least 4 months before the start of the study.

\section{Muscle Biopsy Analysis}

For diagnostic purposes muscle biopsy was obtained from the left deltoid under local anesthesia. Muscle specimens were frozen in liquid nitrogenchilled isopentan, and processed for histologic, his- tochemical, biochemical, and Southern blot analyses, as described below.

\section{Morphology and Histochemistry}

Routine staining for hematoxylin-eosin, Gomori's trichrome, ATPase pH 4.6 and 9.4, as well as oxidative histochemistry for nicotinamide dehydrogenase tetrazolium reductase (NADH-TR), succinate dehydrogenase (SDH), and cytochrome-c oxidase (COX) were performed as previously described (21).

\section{Biochemical Analysis}

In nine cases (Table 1 ) the activity of complex IV (COX; EC 1.9.3.1) was determined spectrophotometrically from isolated muscle mitochondria as described by Rustin et al. (22).

\section{Mitochondrial DNA Analysis}

To study mitochondrial DNA, total DNA was extracted from $10-20 \mathrm{mg}$ of patients' frozen muscle homogenates using standard protocols (23). Southern blot analysis was performed with $4 \mu \mathrm{g}$ of DNA digested with Pvu II, electrophoresed through an $\mathbf{0 . 8 \%}$ agarose gel, then transferred to a nitrocellulose membrane (Bio-Rad Laboratories, Hercules, CA, USA). Human skeletal muscle mtDNA was labeled by random-primer incorporation of digoxigenin-labeled deoxyuridine triphosphate (Boehringer-Mannheim, Roche Diagnostics, Milan, Italy) and used as hybridization probe as described (24). The membrane was hybridized with the labeled probe overnight at $68^{\circ} \mathrm{C}$, then

Table 1. Clinical and laboratory data in MD patients

\begin{tabular}{ccllc}
\hline Case & Age/sex & Diagnosis & $\begin{array}{c}\text { mtDNA } \\
\text { Mutations }\end{array}$ & $\begin{array}{c}\text { Biochemical } \\
\text { COX Activity* }\end{array}$ \\
\hline 1 & $60 / \mathrm{F}$ & ME & Multiple deletions & n.e. \\
2 & $74 / \mathrm{M}$ & CPEO & Single deletion & 640 \\
3 & $74 / \mathrm{F}$ & CPEO & Single deletion & 332 \\
4 & $69 / \mathrm{F}$ & MM & Multiple deletions & 214 \\
5 & $43 / \mathrm{F}$ & CPEO & Multiple deletions & n.e. \\
6 & $59 / \mathrm{F}$ & CPEO & Multiple deletions & 520 \\
7 & $51 / \mathrm{F}$ & CPEO & Single deletion & 496 \\
8 & $64 / \mathrm{F}$ & CPEO & Single deletion & 474 \\
9 & $52 / \mathrm{M}$ & CPEO & Single deletion & 378 \\
10 & $27 / \mathrm{M}$ & CPEO & Single deletion & 284 \\
11 & 33/F & MM & Single deletion & 535 \\
\hline
\end{tabular}

Abbreviations: CPEO, chronic progressive external ophthalmoplegia; ME, mitochondrial encephalomyopathy; MM, mitochondrial myopathy; n.e., not evaluated.

*Nanomoles of substrate utilized $\mathrm{min}^{-1} \mathrm{mg}^{-1}$ of noncollagen proteins in isolated muscle mitochondria. Control values (12 subjects): $906 \pm 203$ (mean \pm SD). 
washed and exposed at film X-OMAT AR (Kodak, Rochester, NY, USA) for $30 \mathrm{~min}$ at room temperature.

\section{Separation of Platelets for Binding Studies}

Platelets from MD patients and healthy volunteers were obtained from venous blood $(20 \mathrm{ml})$ of each subject. After mixing blood with $5 \mathrm{ml}$ of anticoagulant sodium citrate $(2.2 \%)$ and citric acid $(1.2 \%)$, platelet-rich plasma (PRP) was obtained by lowspeed centrifugation $\left(200 \times \mathrm{g}\right.$ for $20 \mathrm{~min}$ at $\left.23^{\circ} \mathrm{C}\right)$. Pelleted platelets obtained by PRP centrifugation at $1500 \times \mathrm{g}$ for $15 \mathrm{~min}$ at $23^{\circ} \mathrm{C}$ were stored at $-80^{\circ} \mathrm{C}$ until PBR binding assay.

\section{${ }^{3}$ H] PK 11195 Binding Studies}

Preparation of platelet membrane and $\left[{ }^{3} \mathrm{H}\right]$ PK 11195 binding assay were performed as previously described (25). Aliquots of the membrane suspensions, containing 50-100 $\mu \mathrm{g}$ of proteins, determined by Lowry's colorimetric method modified by Peterson (26), were incubated with seven different concentrations of $\left[{ }^{3} \mathrm{H}\right]$ PK 11195 , specific activity $85.5 \mathrm{Ci} / \mathrm{mmol}$ (NEN, Boston, MA, USA) (0.5-60 nM) either in the absence (total binding) or in the presence (nonspecific binding) of unlabeled $1 \mu \mathrm{M}$ PK 11195 (Research Biochemical International, Natick, MA, USA) in $0.5 \mathrm{ml}$ final volume of assay buffer, $50 \mathrm{mM}$ Tris- $\mathrm{HCl}, \mathrm{pH}$ 7.4. After incubation for $90 \mathrm{~min}$ at $4^{\circ} \mathrm{C}$, samples were filtered under vacuum through Whatman GF/C filter and washed three times with $5 \mathrm{ml}$ of ice-cold assay buffer. The radioactivity was counted in $4 \mathrm{ml}$ of scintillation cocktail, using a Beckman LS 1800 liquidphase scintillation counter.

\section{Data Analysis}

The equilibrium dissociation constant $\left(K_{\mathrm{d}}\right)$ and the maximum number of binding sites $\left(B_{\max }\right)$ were determined by Scatchard analysis of saturation curves of binding of $\left[{ }^{3} \mathrm{H}\right]$ PK 11195 . The binding parameters were analyzed for each subject individually. Curve fitting was carried out on an IBM compatible personal computer using the software Kinetic, EBDA and Ligand written by McPherson (27) and Graphpad Instat (28). All results are expressed as mean value \pm SEM.

Statistical analysis of the data for intergroup comparison (patients versus controls) was performed using Student's $t$-test.

Correlation between $B_{\max }$ and COX activity values was performed by Spearman test and regression analysis.

\section{Results}

\section{Clinical and Muscle Biopsy Data}

Table 1 reports clinical and laboratory characteristics of MD patients. Eight patients were affected by chronic external progressive ophthalmoplegia (CPEO), sporadic in six and inherited autosomal dominant in two cases, two by myopathy with exercise intolerance (cases 4 and 11), and one by autosomically dominant inherited encephalomyopathy, bipolar disorder, and multiple symmetrical lipomatosis (case 1). All patients matched the accepted criteria for diagnosis of MD: in particular, they showed COX-negative/SDH-positive fibers with a mosaic distribution, and scattered ragged red fibers (RRF) on muscle biopsies. Southern blot analysis showed single (7 cases) or multiple (4 cases) mtDNA deletions in muscle biopsies. Biochemical analysis, performed in nine patients, revealed reduction of COX activity to a variable extent by comparison with the control mean value: below 2 standard deviation (SD) in six patients, between 1 and 2 SD in three patients.

\section{[3H] PK 11195 Binding to Human Platelets' Membrane}

For each platelet membrane sample, obtained from patients and healthy volunteers, $\left[{ }^{3} \mathrm{H}\right] \mathrm{PK} 11195$ highaffinity binding sites were detected. Nonspecific binding (lower than $10 \%$ of total binding) was found to be identical between controls and patients (data not shown). No binding differences among male and female patients were found. Scatchard plots were linear for all analyzed subjects, suggesting the presence of a single population of binding sites (data not shown).

Table 2 summarizes the mean values of $\left[{ }^{3} \mathrm{H}\right] \mathrm{PK}$ 11195 binding parameters $\left(B_{\max }\right.$ and $\left.K_{\mathrm{d}}\right)$ in patients and controls. In patient platelet membranes, the average value of the density of PBR binding sites was decreased respect to control (2387.0 \pm 305.6 $\mathrm{fmol} / \mathrm{mg}$ proteins versus $4889.0 \pm 357.8 \mathrm{fmol} / \mathrm{mg}$ proteins). Moreover, the mean $K_{\mathrm{d}}$ value was higher in patients than in controls $(13.18 \pm 2.06 \mathrm{nM}$ versus $5.63 \pm 0.46 \mathrm{nM})$. Statistical analysis evidenced that these differences were significant $(p<0.05)$ both for $K_{\mathrm{d}}$ and $B_{\max }$ values. No difference was observed between patients with single and multiple mtDNA deletions.

The individual $B_{\max }$ and $K_{\mathrm{d}}$ values are shown in the scattergrams reported in Figure 1 . As far as $K_{\mathrm{d}}$

Table 2. [ $\left.{ }^{3} \mathrm{H}\right]$ PK 11195 binding parameters $\left(K_{\mathrm{d}}\right.$ and $\left.B_{\text {max }}\right)$ on platelet membranes of controls and MD patients

\begin{tabular}{lcc}
\hline & $K_{\mathbf{d}}(\mathbf{n M}) \pm$ SEM & $\begin{array}{c}B_{\max }(\mathrm{fmol} / \mathrm{mg} \\
\text { proteins }) \pm \text { SEM }\end{array}$ \\
\hline Controls $(n=15)$ & $5.63 \pm 0.46$ & $4889.0 \pm 357.8$ \\
Patients $(n=11)$ & $13.18 \pm 2.06^{*}$ & $2397.0 \pm 305.6^{*}$ \\
\hline
\end{tabular}

Values were obtained by Scatchard analysis of saturation isotherms. Each value represents the means \pm SEM of three separate experiments done on triplicate.

${ }^{*} p<0.05$ versus controls. 

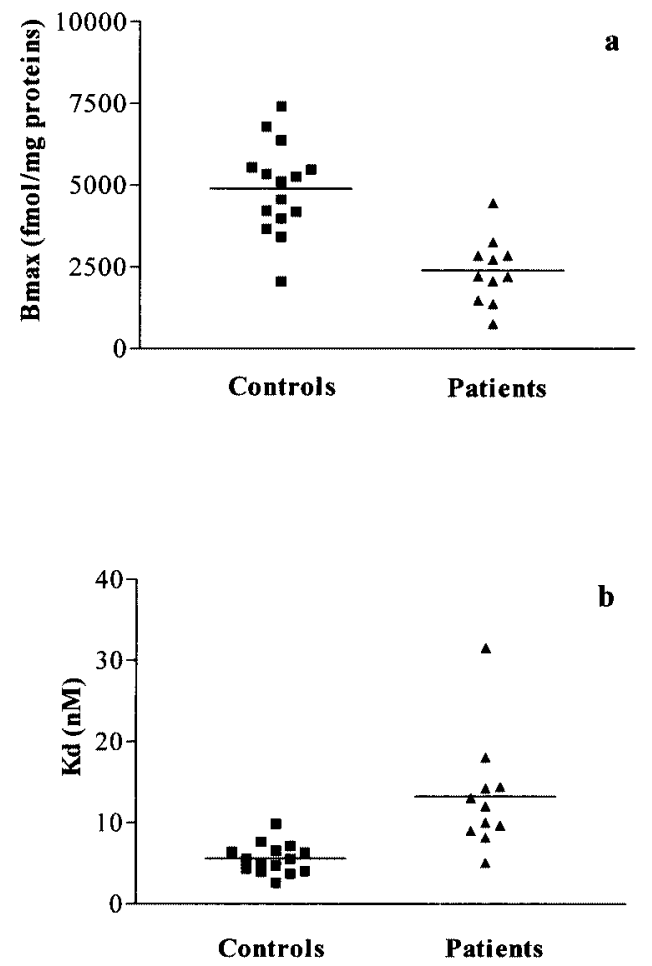

Fig. 1. Scattergrams of individual $B_{\max }$ and $K_{\mathrm{d}}$ values of [ $\left.{ }^{3} \mathrm{H}\right]$ PK 11195 binding to platelet membranes from controls and MD patients. Each point represents an individual subject. $B_{\max }(\mathbf{a})$ and $K_{\mathrm{d}}(\mathbf{b})$ values from controls (ם) and MD patients $(\boldsymbol{\Lambda})$ were obtained by Scatchard analysis of saturation isotherm.

values are concerned, only one patient fit within the control range (mean \pm SEM); another approached the control value regarding $B_{\text {max }}$.

Correlation between the reduction of platelet PBR $B_{\max }$ and that of skeletal muscle COX activity did not rich a significant level. However, performing onetailed analysis (by excluding that patient $B_{\max }$ value that approached the control range), this relationship reached a significant level $(r=0.69, p<0.05)$ (Fig. 2).

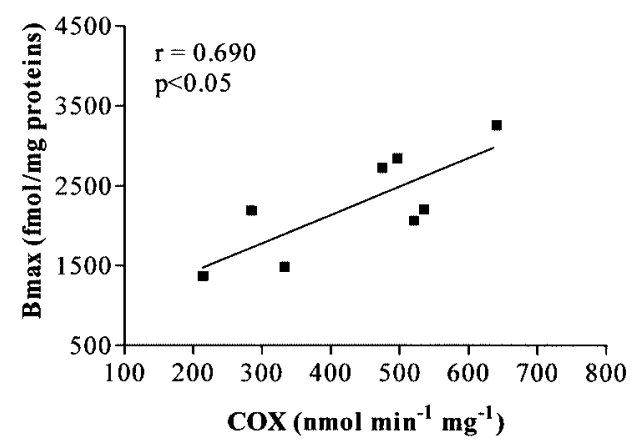

Fig. 2. Correlation between muscle COX activity and platelet PBR $B_{\max }$ values in MD patients. A significant direct relationship was obtained by one-tailed Spearman test and regression analysis $(n=8)$.

\section{Discussion}

PBR is a 18,000 -dalton transmembrane spanning protein, pharmacologically, anatomically, and structurally distinct from CBR. PBR is expressed in almost all the peripheral mammalian tissues, including blood cells, as well as within the brain glial cells $(10,11,29,30)$. A wide spectrum of putative functions has been attributed to PBR, such as steroid biosynthesis (31-33), inflammatory response (34), immune responses (35), insulin secretion (36), mitochondrial respiration (37), and regulation of cellular differentiation and proliferation (38-40). The primary localization of PBR in the mitochondrial membrane and its involvement in the MPT-pore complex, suggest that the PBR takes part in the regulation of mitochondrial permeability and induction of apoptosis. Several papers report that specific PBR ligands may induce apoptosis directly (41-43) or may facilitate apoptosis induction by several agents in different cells (44-46).

Recently, another important component of MPTpore, the adenine nucleotide translocator (ANT), has been reported mutated in some autosomal dominant mitochondrial disorders, clinically associated with progressive external ophthalmoplegia (47-49). Because it has been demonstrated that, at mitochondrial level, ANT co-solubilizes with the voltage-dependent anion channel and PBR $(50,51)$, suggesting a functional association of these important constitutive elements of the MPT-pore complex, in the present paper we investigated PBR binding characteristics in platelets from patients affected by different form of MD, molecularly characterized by the presence of single or multiple deletions of mtDNA.

To the best of our knowledge, the present study is the first observation of modifications in the binding of $\left[{ }^{3} \mathrm{H}\right]$ PK 11195, a specific PBR ligand, on the membranes of platelets from patients affected by MD. In these patients, an alteration in kinetic binding parameters ( $K_{\mathrm{d}}$ and $B_{\max }$ values) was clearly present. The decrease of binding site density was recorded in all analyzed patients either with multiple or single mtDNA deletions. These data indicate that biochemical alterations occurs at the peripheral level in these neurologic disorders. It is well known that abnormal PBR density frequently occurs in pathologic conditions, including neurometabolic or neurodegenerative disorders (12). In particular, a decrease in the density of PBR has been found in platelets or lymphocytes of patients with hepatic encephalopathy (52) and with Parkinson's disease (PD) (53). Furthermore, in the platelets of patients affected by Alzheimer's disease (AD), either an increase or a decrease has been found $(54,55)$. Moreover, PBR seems to represent an intermediate site for the modulation of the mitochondrial respiratory function $(56,57)$. PBR ligands have been thought to increase state IV and decrease state III respiration rates, so that activation of the PBR significantly decreases the respiratory control ratio. Further studies 
have indicated that the PBR can regulate mitochondrial swelling, and it is involved in succinatecytochrome c oxidoreductase activity (58).

Based on these observations, it has been suggested that changes in PBR density may, at least in part, reflect the alterations of the mitochondrial respiratory function $(53,55)$. In fact, a reduced enzymatic activity of mitochondrial respiratory chain has been observed both in brain and in the peripheral tissues of patients affected by AD or PD (59-61). In MD with large-scale mtDNA rearrangements, biochemical analysis, usually carried out on muscle biopsies or platelets of patients, frequently show alterations of enzymatic mitochondrial respiratory chain activity, consisting of deficiency of one or more of the mitochondrial respiratory chain complexes $(62,63)$.

Because mitochondrial metabolism is not only the principal source of high energy intermediates, but also of reactive oxygen species (ROS), it has been suggested that inherited or acquired mitochondrial defects could cause cell degeneration as consequence of both energy defects and oxidative damage (13). Considering the primary mitochondrial localization of PBR, its role in regulating some mitochondrial functions, and its sensitivity to ROS, the question of PBR role appears therefore relevant not only in those neurodegenerative and neuropsychiatric pathologies, where mitochondrial dysfunction has been considered to play a pathogenic role, but also probably in other MD as well.

It might be hypothesized that in our MD patients the decrease of PBR binding sites is related to mitochondrial dysfunction; in fact, all the examined patients showed a reduction of COX activity as consequence of the pathogenic mtDNA deletions and there was a trend in the relationship between the decrease of platelet PBR density and skeletal muscle COX activity. These results suggest that the metabolic status of cell could be relevant in modulating PBR density in MD.

Our findings may provide new insights into the pathogenesis of MD and form the basis of future studies on function of MPT-pore, where PBR represents an important constituent.

\section{Acknowledgments}

The financial support of Telethon-Italy (project $\mathbf{n}^{\circ}$ 1179c) and DNA/Tissue Bank for Neuromuscular Disorders, Muscle Disease Center Department of Neurosciences of University of Pisa, are gratefully acknowledged.

We also thank Dr M.L. Manca for her helpful advice on statistical analysis of the data.

\section{References}

1. Di Mauro S, Schon FA. (2001) Mitochondrial DNA mutations in human disease. Am. J Med. Genet. 106: 18-26.

2. Cassarino DS, Benett JP Jr. (1999) An evaluation of the role of mitochondria in neurodegenerative diseases: mitochondrial mutations and oxidative pathology, protective nuclear responses, and cell death in neurodegeneration. Brain Research Reviews 29: 1-25.

3. Green DR, Reed JC. (1998) Mitochondria and apoptosis. Science 281: 1309-1312.

4. Kroemer G, Dallaporta B, Resche-Rigon M. (1998) The mitochondrial death/life regulator in apoptosis and necrosis. Annu. Rev. Physiol. 60: 619-642.

5. Susin SA, Zamzami N, Kroemer G. (1998) Mitochondria as regulators of apoptosis: doubt no more. Biochim. Biophys. Acta 1366: 151-165.

6. Monici MC, Toscano A, Girlanda P, et al. (1998) Apoptosis in metabolic myopathies. Neuroreport 9: 2431-2435.

7. Zhang J, Yoneda M, Naruse K, et al. (1998) Peroxide production and apoptosis in cultured cells carrying mtDNA mutation causing encephalomyopathy. Biochem. Mol. Biol. Int. 46: 71-79.

8. Zoratti M, Szabò I. (1995) The mitochondrial permeability transition. Biochim. Biophys. Acta 1241: 139-176.

9. Joseph Liauzun E, Farges R, Delmas P, et al. (1997) The Mr 18,000 subunit of the peripheral-type benzodiazepine receptor exhibits both benzodiazepine and isoquinoline carboxamide binding sites in the absence of the voltage-dependent anion channel or of the adenine nucleotide carrier. J. Biol. Chem. 272: 28102-28106.

10. Brauestrup C, Squires RF. (1977) Specific benzodiazepine receptors in rat brain characterized by high-affinity $\left[{ }^{3} \mathrm{H}\right] \mathrm{di}-$ azepam binding. Proc. Natl. Acad. Sci. U. S. A. 74: 3805-3809.

11. Canat X, Guillaumont A, Bouaboula M, et al. (1993) Peripheral benzodiazepine receptor modulation with phagocyte differentiation. Biochem. Pharmacol. 46: 55 1-554.

12. Gavish M, Bachman I, Shoukrun R, et al. (1999) Enigma of the peripheral benzodiazepine receptor. Pharmacol. Rev. 51: 629-650.

13. Casellas P, Galiegue S, Basile AS. (2002) Peripheral benzodiazepine receptors and mitochondrial function. Neurochem. Int. 40: $475-486$.

14. Drugan RC, Basile AS, Crawley JN, et al. (1986) Inescapable stress decreases Ro5-4864 (4'-chlorodiazepam) binding in rat brain and peripheral tissue. Pharmacol. Biochem. Behav. 24: 1673-1677.

15. Drugan RC, Holmes PV, Scher DM, et al. (1995) Environmentally-induced changes in peripheral benzodiazepine receptors are stressor and tissue specific. Pharmacol. Biochem. Behav. 50: 551-562.

16. Basile AS, Weissman BA, Skolnick P. (1987) Maximal electroshock increases the density of peripheral-type benzodiazepine receptors in mouse cerebral cortex. Brain Res. Bull. 19: 1-7.

17. Desjardins P, Todd KG, Hazell AS, Butterworth RF. (1999) Increased peripheral-type benzodiazepine receptor sites and mRNA in thalamus of thiamine-deficient rats. Neurochem. Int. 35: 363-369.

18. Owen F, Poulter M, Waddington JL, et al. (1983) [ $\left.{ }^{3} \mathrm{H}\right]$ Ro5-4864 and $\left[{ }^{3} \mathrm{H}\right]$ flunitrazepam binding in kainate-lesioned rat striatum and temporal cortex of brains from patients with senile dementia of the Alzheimer subtype. Brain Res. 278: 373-375.

19. Messmer K, Reynolds GP. (1998) Increased peripheral benzodiazepine binding sites in the brain of patients with Huntington's disease. Neurosci. Lett. 241: 53-56.

20. Lacor P, Benavides J, Ferzaz B. (1996) Enhanced expression of the PBR and its endogenous ligand ODN in the regenerating adult rat sciatic nerve. Neuroscience Lett. 220: 61-65.

21. Sciacco M, Bonilla E. (1996) Cytochemistry and immunocytochemistry of mitochondria in tissue sections. Meth. Enzymol. 264: 509-521.

22. Rustin P, Chretien D, Bourgeron T, et al. (1994) Biochemical and molecular investigations in respiratory chain deficiencies. Clin. Chim. Acta 228: 35-51.

23. Sambrook J, Russel DW. (2001) Molecular Cloning: A Laboratory Manual. Cold Spring Harbor, N: Cold Spring Harbor Laboratory Press; pp. 6.4-6.11.

24. Moraes CT, Shanske S, Tritschler HJ, et al. (1991) mtDNA depletion with variable tissue expression: a novel genetic 
abnormality in mitochondrial diseases. Am. J. Hum. Genet. 48: 492-501.

25. Pavese N, Giannaccini G, Betti L, et al. (2000) Peripheral-type benzodiazepine receptors in human blood cells of patients affected by migraine without aura. Neurochem. Int. 37: 363-368.

26. Peterson GL. (1977) A simplification of the protein assay method of Lowry et al. which is more generally applicable. Anal. Biochem. 83: 346-356.

27. McPherson GA, Grant A. (1985) Analysis of radioligand binding experiments. A collection of computer programs for the IBM PC. J. Pharmacol. Methods 14: 213-288.

28. Matulsky H, Leatherbarrow RJ. (1990) Grafit Version 3.0. Staines, UK: Erithacus Software Ltd.

29. Schoemaker H, Boles RG, Horst WD, Yamamura HI. (1983) Specific high-affinity binding sites for [3H]Ro 5-4864 in rat brain and kidney. J. Pharmacol. Exp. Ther. 225: 61-69.

30. Woods MJ, Williams DC. (1996) Multiple forms and location for the peripheral-type benzodiazepine receptor. Biochem. Pharmacol. 52: 1805-1814.

31. Papadopoulous V, Guarnieri P, Krueger KE, et al. (1992) Pregnenolone biosynthesis in $\mathrm{C} 6$ glioma cell mitochondria: regulation by a diazepam binding inhibitor mitochondrial receptor. Proc. Natl. Acad. Sci. U. S. A. 89: 5118-5122.

32. Papadopoulous V. (1993) Peripheral-type benzodiazepine/ diazepam binding inhibitor receptor: biological role in steroidogenic cell function. Endocr. Rev. 12: 222-240.

33. Papadopoulous V, Amri H, Boujrad N, et al. (1997) Peripheral benzodiazepine receptor in cholesterol transport and steroidogenesis. Steroids 62: 21-28.

34. Torres SR, Nardi GM, Ferrara P, et al. (1999) Potential role of peripheral benzodiazepine receptors in inflammatory responses. Eur. J. Pharmacol. 385: R1-R2.

35. Taupin V, Herbelin A, Descamps-Latscha B, Zavala F. (1991) Endogenous angiogenic peptide, ODN-diazepam-binding inhibitor, and benzodiazepines enhance the production of interleukin-1 and tumor necrosis factor by human monocytes. Lymphokine Cytokine Res. 10: 7-13.

36. De Stefanis P, Impagnatiello F, Berkovich A, Guidotti A. (1995) Inhibitory effect of ODN, a naturally occurring processing product of diazepam binding inhibitor, on secretagogues-induced insulin secretion. Regul. Pept. 56: 153-165.

37. Hirsch JD, Beyer CF, Malkowitz L, et al. (1989) Mitochondrial benzodiazepine receptors mediate inhibition of mitochondrial respiratory control. Mol. Pharmacol. 35: 157-163.

38. Alho H, Varga V, Krueger KE. (1994) Expression of mitochondrial benzodiazepine receptor and its putative endogenous ligand diazepam binding inhibitor in cultured primary astrocytes and C6 cells: relation to cell growth. Cell Growth Differ. 5: 1005-1014.

39. Landau M, Weizman A, Zoref-Shani E, et al. (1998) Antiproliferative and differentiating effects of benzodiazepine receptor ligands on B16 melanoma cells. Biochem. Pharmacol. 56: 1029-1034.

40. Hardwick M, Fertikh D, Culty M, et al. (1999) Peripheraltype benzodiazepine receptor (PBR) in human breast cancer: correlation of breast cancer cell aggressive phenotype with PBR expression, nuclear localization, and PBR-mediated cell proliferation and nuclear transport of cholesterol. Cancer Res. 59: $831-842$.

41. Tanimoto Y, Onishi Y, Sato Y, Kizaki H. (1999) Benzodiazepine receptor agonists modulate thymocyte apoptosis through reduction of the mitochondrial transmembrane potential. Jpn. J. Pharmacol. 79: 177-183.

42. Fischer R, Schmitt M, Bode JG, Haussinger D. (2001) Expression of the peripheral-type benzodiazepine receptor and apoptosis induction in hepatic stellate cells. Gastroenterology 120: 1212-1226.

43. Chelli B, Falleni A, Salvetti F, et al. (2001) Peripheral-type benzodiazepine receptor ligands: mitochondrial permeability transition induction in rat cardiac tissue. Biochem. Pharmacol. 6: 695-705.
44. Hirsch T, Decaudin D, Susin SA, et al. (1998) PK 11195, a ligand of the mitochondrial benzodiazepine receptor, facilitates the induction of apoptosis and reverses Bcl-2 mediated cytoprotection. Exp. Cell Res. 241: 426-434.

45. Ravagnan L, Marzo I, Costantini P, et al. (1999) Lonidamine triggers apoptosis via a direct, Bcl-2-inhibited effect on the mitochondrial permeability transition pore. Oncogene 18: 2537-2546.

46. Larochette N, Decaudin D, Jacotot E, et al. (1999) Arsenite induces apoptosis via a direct effect on the mitochondrial permeability transition pore. Exp. Cell Res. 249: 413-421.

47. Kaukonen J, Juselius JK, Tiranti V, et al. (2000) Role of adenine nucleotide translocator 1 in mtDNA maintenance. Science 289: 782-785.

48. Napoli L, Bordoni A, Zeviani M, et al. (2001) A novel missense adenine nucleotide translocator- 1 gene mutation in a Greek adPEO family. Neurology 26: 2295-2298.

49. Siciliano G, Tessa A, Petrini S, et al. Autosomal dominant external ophthalmoplegia and bipolar affective disorder associated with a mutation in the ANT-1 gene. Neuromuscul. Disord., in press.

50. McEnery MW, Snowman AM, Trifeletti RR, Snyder SH. (1992) Isolation of the mitochondrial benzodiazepine receptor: association with the voltage-dependent anion channel and the adenine dinucleotide carrier. Proc. Natl. Acad. Sci. U. S. A. 89: 3170-3174.

51. Anholt RR, Pedersen PL, De Souza EB, Snyder SH. (1996) The peripheral-type benzodiazepine receptor: localization to the mitochondrial outer membrane. J. Biol. Chem. 261: 576-580.

52. Ferrero P, Rocca P, Benna P, et al. (1991) A study of [3H]PK 11195 binding to peripheral-type benzodiazepine receptors on human lymphocytes. Evidence of decreased binding in hepatic encephalopathy. J. Neurol. Sci. 102: 209-219.

53. Bonuccelli U, Nuti A, Del Dotto P, et al. (1991) Platelet peripheral benzodiazepine receptors are decreased in Parkinson's disease. Life Sci. 48: 1185-1190.

54. Bidder M, Ratzoni G, Weitzman A. (1990) Platelet benzodiazepine binding in Alzheimer's disease. Biol. Psychiatry. 28: 641-643.

55. Bongioanni P, Castagna M, Mondino C, et al. (1997) Platelet and lymphocyte benzodiazepine binding in patients with Alzheimer's disease. Exp. Neurol. 146: 560-566.

56. Anholt RR. (1986) Mitochondrial benzodiazepine receptors as potential modulators of intermediary metabolism. Trend. Pharmacol. Sci. 12: 506-511.

57. Hirsch JD, Beyer CF, Malkowitz L, et al. (1988) Characterisation of ligand binding to mitochondrial benzodiazepine receptors. Mol. Pharmacol. 34: 157-163.

58. Moreno Sanchez R, Hougue BA, Bravo C, et al. (1991) Inhibition of substrate oxidation in mitochondria by peripheraltype benzodiazepine receptor ligand AHN 086. Biochem. Pharmacol. 41: 1479-1484.

59. Hattory N, Kitada T, Matsumine H. (1998) Molecular genetic analysis of a novel Parkin gene in Japanese families with autosomal recessive juvenile parkinsonism: evidence for variable homozygous deletions in the Parkin gene in affected individuals. Ann. Neurol. 44: 935-941.

60. Parker WD Jr, Mahr NJ, Filley CM, et al. (1994) Reduced platelet cytochrome c oxidase activity in Alzheimer's disease. Neurology 44: 1086-1090.

61. Parker WD Jr, Parks J, Filley CM, Kleinschmidt-DeMasters BK. (1994) Electron transport chain defects in Alzheimer's disease brain. Neurology 44: 1090-1096.

62. Holt IJ, Harding AE, Cooper JM, et al. (1989) Mitochondrial myopathies: clinical and biochemical features of 30 patients with major deletions of muscle mitochondrial DNA. Ann. Neurol. 26: 699-708.

63. Rahman S, Blok RB, Dahl HH, et al. (1996) Leigh syndrome: clinical features and biochemical and DNA abnormalities. Ann. Neurol. 39: 343-351. 